\title{
Resistance to Change Processes and Strategies for the Implementation of Harmonization Reforms: The Separation of the Health Care Expenditure in the Regional Financial Statements
}

\author{
Rainero Christian ${ }^{1}$, Migliavacca Alessandro ${ }^{2}$, Puddu Luigi ${ }^{3} \&$ Modarelli Giuseppe $^{4}$ \\ ${ }^{1}$ Associate Professor of Business Management and Public Sector, Management, Department of Management, \\ University of Turin, Italy \\ 2 Assistant Professor of Public Sector Management, Ph.D. Research Fellow, Department of Management, \\ University of Turin, Italy \\ 3 Full Professor of Business Management and Public Sector Management, Department of Management, \\ University of Turin, Italy \\ ${ }^{4}$ Ph.D Student in Business and Management, Department of Management, University of Turin, Italy \\ Correspondence: Giuseppe Modarelli, Business and Management, University of Turin, Italy. E-mail: \\ giuseppe.modarelli@unito.it
}

Received: December 22, 2017

Accepted: January 31, 2018

Online Published: February 25, 2018

doi:10.5539/ijbm.v13n3p42

URL: https://doi.org/10.5539/ijbm.v13n3p42

\begin{abstract}
The Legislative Decree n. 118/2011, in setting the rules for the harmonization of the financial accounting of the local governments, represents a further progress for the accounting process also for the health care. In the specific case the article 20 defines a precise identification perimeter of revenue and expenditure related with National Health Service (NHS) by the regulations in the regional financial statements, in a way to make possible an immediate comparability between the Health Care incomes and expenditures in the Regional financial statement. The aim of this paper, always referred to the Rational Management based on financial statement, focuses the attention on the possible correlation between organizational responses to institutional pressure and the theoretical roles of accounting, tracing lines of best practices compliance or not on the sample above explained.
\end{abstract}

Keywords: accounting processes, health care accounting, rational management, organizational behaviors, roles of accounting

\section{Introduction}

The Italian National Health Service decision-making is defined by the levels of funding provided, and it is organized in a twofold level. On one hand, the State defines the Basic Level of Health Care services (BLH, namely LEA in the Italian acronym), and ensures the appropriate financing resources, consistently with the public finance's constraints and according to efficiency and pertinence of the delivered services. On the other hand, the Regions organize their Regional Health Care Services (RHS), to deliver the services included in the $\mathrm{BLH}$ and for the planning and management of the health care services in the territory. This management model should aim to incentivize and subsidize the "virtuous" Regional Health Care Services, which improve the efficiency and effectiveness of the BLH delivery (Puddu et al., 2016). This process allows the improvement of the budget, particularly important for those Regions in situation of deficit, and it also maximizes the pertinent satisfaction of the health care needs of the population, consistently with the available resources. The legislative framework reform of the last decade has kick-started the implementation of a Rational Management model (Puddu and Di Russo, 2013; Rainero et al., 2016) in the Health Care to pursue gradually and effectively the aforementioned objectives.

The Legislative Decree n. 118/2011, in setting the rules for the harmonization of the financial accounting of the local governments, represents a further progress for the accounting process also for the health care. The reformed regulation introduced a few tools for a better accounting of the Health Care sector of the Local Governments (namely, the Regions). First of all, there has been introduced the Centralized Healthcare Management (CHM, 
namely GSA in the Italian acronym). Furthermore, it introduced a separate bank account for the Health Care related cash flows and treasury management. Lastly, in the final financial statement, the Regions have to separate and outline the Health Care incomes and expenditures from the other accounts, by highlighting the related accounts or by other means (e.g. in a separate explanatory statement). This separation should allow the immediate comparability between the Health Care incomes and expenditures in the Regional financial statement. Thus, it should be easily verifiable whether the resources are correctly allocated and which further resources have to be provided to the Regions.

More specifically (Note 1), the following income voices must be identified: (i) the ordinary current health funding, including active planned patients mobility between territories; (ii) the additional current health funding, including the additional funding for higher levels of Health Care compared with the BHL; (iii) the regional funding of previous Health Care deficits; (iv) the Health Care funding for investments, including the Health Care facilities' incomes.

From the expenditure side, the following accounts must be highlighted: (i) the expenditure for the current Health Care funding; (ii) the expenditure for the additional Health Care funding (over the BLH); (iii) the coverage for the previous years' deficits; (iv) the Health Care investments.

The model outlined for financing and related to the reporting of revenue and expenditure in the regional financial statements, allows to underline a precise knowledge of the "state of health" regarding the service mentioned above, related with each region. This research tries to respond to different needs:

1) Verifying the state of implementation of the provision required to circumscribe revenue and expenditure related with National Health Service (NHS) by the regulations in the regional financial statements;

2) Verifying the methods of implementation and the readability of the information provided in favor of citizens, controllers and stakeholders;

3) Investigating on the provision's capacity to inform and identifying some critical issues.

To obtain a precise identification of the criteria for investigation and interpretation, and to meet the research objectives, the following paragraph introduces the theoretical interpretative framework to which we refer; the third paragraph describes the methods of investigation; the fourth paragraph shows the analysis and the results of the research; the fifth paragraph concludes.

\section{Interpretation Theoretical Framework}

\subsection{The Role of Accounting (Miller and Power, 2013) and the Readability of Accounting Documents}

The separation of health expenditure in the Regional Financial Statement is considered to be an informative duty in the context of the Italian Public Sector Accounting harmonization reform. It constitutes a fundamental tool for the identification of the correct management and destination of the financial resources allocated for the Italian National Health Service, as well as for the identification of additional resources allocated by the Regions for their health care services, and their usage to cover which typology of expense. As a reporting tool, it could have different shapes, provided that they are consistent with the law enforcements, and therefore it could fulfill different purposes. First of all, each reporting tool is a synthesis of the accounting process that takes place throughout the year. The aim of this process, and ultimately the final purpose of reporting in general, are identified by the international literature (Miller and Power, 2013) according to the following capabilities:

1) Defining of "territory" and "magnitude" of the activity (Territorializing);

2) Intermediate information about the activity (Mediating);

3) Possibility of judgement on the activity (Adjudicating);

4) Accountability and responsibility (Subjectivizing).

Accounting processes have a twofold power, one transformative and one constitutive, about the economic-financial health of the people and companies them account for (Miller, in Hopwood and Miller, 1994, pp. 1-39) and they are a critical tool, in a context of rational management based on financial statement, without it would be impossible to make decisions in an informed context (Migliavacca et al., 2016; Miller and Power, 2013). First of all, the transformative and constitutive powers guarantee full awareness of results regarding management results. In addition, those powers have a role in defining the "territory", being it considered as the economic space that the person, or the company occupies into society and environment (Ferrero, 1968).

Furthermore, the accounting and reporting process have the goal to identify the information that the company, or the person, wants to communicate outside, as well as the ways in which they want to communicate it. 
Accounting is so subtended and influenced by a set of ideas and values of the company, ultimately of the people who govern it. This process, called informative intermediation (Miller and Power, 2013), has a double value: the first one is to communicate outside the health of the business, the second one is to communicate its interpretation and evaluation by the management.

The third aspect of the accounting process, and ultimately the reporting that derives from it, is about the possibility of being submitted to the stakeholders' judgement and their opinion on the base of the information promoted by reporting. In fact, the very purpose of accounting and reporting is to provide the information on the basis of each economic actors and stakeholders make decisions, modifying their preferences (March, 1987). Finally, the accounting and reporting process has the goal to subject the actions implemented by the company and to empower people who govern it. This aspect is expressed in the possibility of subjecting companies to regulation and control on the basis of financial statement data; on the other hand, it is expressed in the possibility and obligation to choose in which way and what kind of rules to report their performances. The separation of the income and expenses of the Italian Regional Health Service (RHS), into the Regional general financial accounts, represents an accounting and reporting tool based on all the aspects indicated above:

1) it allows to provide a clear and precise information, even if extremely brief, on the aspects identified (methods of financing the expenditure, methods of disbursement of resources and compliance with the Essential Assistance Levels);

2) it allows to identify the perimeter that the health care occupies in the regional financial statement and the weight that it has on the own resources allocated by the single Region;

3) it defines, at the national consolidated level, the methods and financial needs required by regions, according with the principles of equality, universality of service and equalization of the regions' financial capacity;

4) it guarantees information to citizens on the correct use of the financial resources allocated to the RHS;

5) it provides necessary information to control by the bodies at various levels (auditors, Court of Auditors, Ministries);

6) it makes possible to identify deficiencies in the regions;

7) it gives the accountability to the regional top management bodies on the resources allocation choice and, at least, to respect the Essential Assistance Levels and the correct management of the NHS, ensuring the universality principle of the service and respect ethics that necessarily underlie public health care.

A final but fundamental aspect that underlies the usefulness of the reporting tool is, finally, the information comprehensibility provided according to the modalities imposed or chosen: in this sense, an information contained in a financial statement or in an incomprehensible accounting or unreadable ones, it could appears completely useless to pursue previously identified goals (Smith and Smith, 1971).

\subsection{Strategic Behavior in Organizational Changes}

In the outlined context of reform, a fundamental issue is the strategic response to the organizational change, which can be defined, in this paper, as an institutional change process. It is therefore possible to proceed with an interpretative analysis of the approaches and responses to the institutional change process referred to the reporting rules to constitute the regional health care perimeter regarding its income and expenditure, based on the work of Oliver (Oliver, 1991; Pache and Santos, 2010) on organizational strategic responses to institutional change process. In his work, Oliver builds a trait-d'union between the (neo)institutional theory and the resource dependency theory of organizations.

Thus, while the first one mentioned identifies the institutional environment, composed by norms and values of different stakeholders, in a way able to reflect organizational methods, acting correctly and therefore adopting structures and processes to satisfy external actors, the second one identifies the organizational behavior in which organizations try to minimize dependence between the others, with a particular regard to the acquisition of important resources, and to influence the environment with the goal to obtain the availability of resources.

The theoretical scheme which we referred could be easily linked with a fragmented sector as the healthcare sector (Pache and Santos, 2010) and the public sector, where institutional pressures and regulations are highly fragmented and sometimes contradictory (Heimer, 1999; Kitchener, 2002; Nigam and Ocasio, 2010; Reay and Hinings, 2009; Scott, 1983; Shipilov et al., 2010). In this context, on the one hand, institutional organizational behavior identifies organizational behaviors to survive and persist over the time through the research of an internal coherence and compliance referred to the external environment expectations; on the other hand, organizations achieve success fighting for their independence and autonomy and they will do whatever necessary 
to avoid an excessive over-dependence with the environment and maintaining resources control, reducing the level of uncertainty.

The intent is to identify the different strategic responses that organizations take in place as a result of institutional pressures to compliance exerted on them and in order to outline a conceptual context for the prediction or identification of the different strategies. In this sense, the use of two distinct organizational theories makes it possible to overcome the problems detected over time on the institutional theory, for example the absence of attention to the role of internal institutional propulsive thrust and the active response to institutional pressures and their expectations (Abernethy and Stoelwinder, 1995; Clemens and Douglas, 2005; Covaleski and Dirsmith, 1988; DiMaggio, 1988; Greenwood et al., 2011; Modell, 2001; Perrow, 1985; Powell, 1985; Scott, 2001). In this way, it is outlined how organizational behavior could be different from passive acquiescence to active resistance in response to institutional pressure, depending on its nature and context. The theoretical framework used for our analysis is based on five of behavioral responses to the institutional change process identified in Oliver's work, and on the identification criteria related with them. The behaviors of interest, in particular, are five:

- Acquiescence;

- Compromise;

- Avoidance;

- Defiance;

- Manipulation.

Acquiescence is the organizational behavior characterized by adherence to change, using passive behaviors (Habit), partially active (Imitation) or totally active (Compliance). The passive acquiescence behavior, or Habit, consists in going on the activity with a blindly adaptation to preconceived or axiomatic rules to modifying the own organizational behavior (Scott, 1987). The Imitation behavior, coherent with the concept of isomorphism of the institutional theory, consists in a conscious adjustment implemented through the imitation of established institutional models (efficient and successful institutions, established practices, etc...) (DiMaggio and Powell, 1983; Galaskiewicz and Wasserman, 1989). Compliance behavior consists in conscious and unconditional obedience or the internalization of norms, values, and fulfillments in own organizational processes (DiMaggio, 1988; Meyer et al., 1987; Meyer and Scott, 1992; Salancik and Pfeffer, 1978).

Compromise behaviors, on the other hand, become real when the organizational change, if fully implemented, could have not functional operational repercussions or inadequate to the organizational structure. Under these circumstances, the organization could put in pace organizational changing with attitudes of Balancing, Pacifying or Bargaining. Balance behavior is a tactical response to organizational changing, which consists in balancing a set of requests and of changing, in response to multiple incentives or expectations, in a way to balance and equalize the internal interests and multiple stakeholders' interests (for instance, in Powell and Friedkin, 1986). Pacifying behavior is a type of partial "conformity" to expectations and external incentives, in which organizations tend, for example, to comply themselves applying a minimum standard required by legislation (Meyer et al., 1987; Reay and Hinings, 2009; Scott, 1983) generating a resistance to pressures and institutional changing. Bargaining behavior is a more active than compromise one, in which the organization becomes the main part of changing, requiring to the subjects that stimulate this changing to reduce, adjust or lighten the requests necessary for organizational changing (Salancik and Pfeffer, 1978).

Avoidance behaviors constitute a category of response present in both theories mentioned (Meyer, 1983; Meyer and Rowan, 1977; Powell, 1988; Salancik and Pfeffer, 1978; Thompson, 1967), and consists in the organizational attempt to avoid compliance, through strategies of Concealment, Buffering or Escaping. Concealment strategies, in particular, consist in masking non-compliance behind a false compliance, through the construction of plans or procedures in response to the required organizational changes, false application of compliance or symbolic acceptance of the rules (Meyer and Rowan, 1977). Buffering strategies, on the other hand, consist in the organizational attempt to reduce the fulfillment to a minimum, with a contraction of the field of inspection, scrutiny or evaluation by external subjects, through the detachment or division of the technical activities (Salancik and Pfeffer, 1978; Thompson, 1967). Last but not the least, Escaping strategies consist in organizational attempt to exit from the field of application of changing or new norm request (Hirschman, 1970), through a modification of its aims, activities or formal requirements.

The fourth behavior, identified with the term of Defiance, is a more active form of contrast to institutional changing and expressed itself through three tactics by different degrees and scope. The first tactic, of Dismissing, consists in ignoring the stimulus of changing or the imposed rule. This kind of reaction is typically exercised in 
cases in which the power to influence changing by external subjects, or the possibility of being found in deficiency, is relatively low. For example, Salancik (1979) outlined a direct correlation between readiness to implement a new imposed requirement by law and the degree of dependence of resources to the regulatory government. The second tactic identified with the term of Challenge takes in place a more active rejection against the imposed legislation and changing incentive, in which the organization promotes alternatives and contrasting ways against the norm or the motivation provided to affirm own values. For example, when there is an imposing rules process for schools, some may ignore that rules and, do battles to contrast them, and then it could be identified as Challenge (Oliver, 1991). The third tactic is about the Attack, more aggressive than the previous one, in which the ideological crash for the affirmation of values is exacerbated and the refusal to apply the legislation empowers an active protest.

The fifth and last one consists in a Manipulation behavior, that found itself in an active influence to modify the imposed norm or the types of changing. It expresses itself through tactics of cooptation, influence or direct control. These tactics represent the most active response to the institutional change process, in which pressures is not considered in any way obliged, but subject to influence, recreation, alteration or control. The co-optation tactic (Co-opt) is expressed in involving the main changing proponent actor, the main motivator for example the board of directors or directional bodies (Burt, 1983; Pennings, 1980; Salancik \& Pfeffer, 1978). Influence tactic, on the other hand, mainly implemented towards institutionalized values and beliefs, performance evaluation criteria or practices, standardized uses and activities. Finally, Direct Control tactic is expressed in direct efforts of influence and exercise of power on external subjects who are the main changing proponent and exert pressure on the organization.

Table 1. Strategic responses to institutional processes - Adapted from Oliver, 1991

\begin{tabular}{lll}
\hline Strategy & Tactic & Example \\
\hline \multirow{4}{*}{ Aquiescence } & Habit & Follow invisible and basic assumptions \\
& Imitation & Mimic institutional models \\
& Compliance & Obey the commands and accept the rules \\
& Balance & Balance the expectations of more than one external subject \\
Compromise & Pacify & Adoption of essential minimal behaviors \\
& Bargain & Negotiation with external subjects \\
& Concealment & Hiding non-compliance \\
Avoidance & Buffer & Reduce institutional contacts \\
& Escape & Change objectives, activities or goals \\
& Dismiss & Ignore explicit rules or values \\
Defiance & Challenge & Contest rules and requests \\
& Attack & Assault directed to the influencing subject \\
& Co-opt & Co-opt influencing subjects in the governing body \\
Manipulation & Influence & Influence directly the values and criteria of changing \\
& Control & Domination of institutional processes and influencing subjects \\
\hline
\end{tabular}

\section{Methodology}

\subsection{Field of Inquiry and Time of the Research}

As aforementioned, the legislative provisions explained in the Article 20 of Legislative Decree 118/2011, contains regulations on the "transparency of health care accounts and resources allocation for financing each regional health services",

To better understand the compliance panorama at the national level, we proceeded with a document analysis methodology (Hoque et al., 2017; Saunders et al., 2009) based on qualitative research. This methodology could, on the one hand, outline the compliance or non-compliance phenomena in the several regions. On the other hand, it could uncover some of the best practices of application that occurred. To do this, we took into account what the Regional Council and government actually published on the institutional websites, in the section named transparent administration - financial statements, and on the Local Official Bulletin.

From the documents analysis, conducted with a systematic and homogeneous approach, we outlined the sensible data for clustering the organizational "psychological-behavioral" response to the normative reform (institutional pressure conflicting with the previous regulation, Pache and Santos, 2010). In particular, in this case we outlined 
the behaviors of the Italian Regions' Councils. As highlighted in the theoretical framework, C. Oliver in 1991 affirmed that organizations can take in place different types of response to external institutional pressure, this framework is shown in the following illustrative scheme.

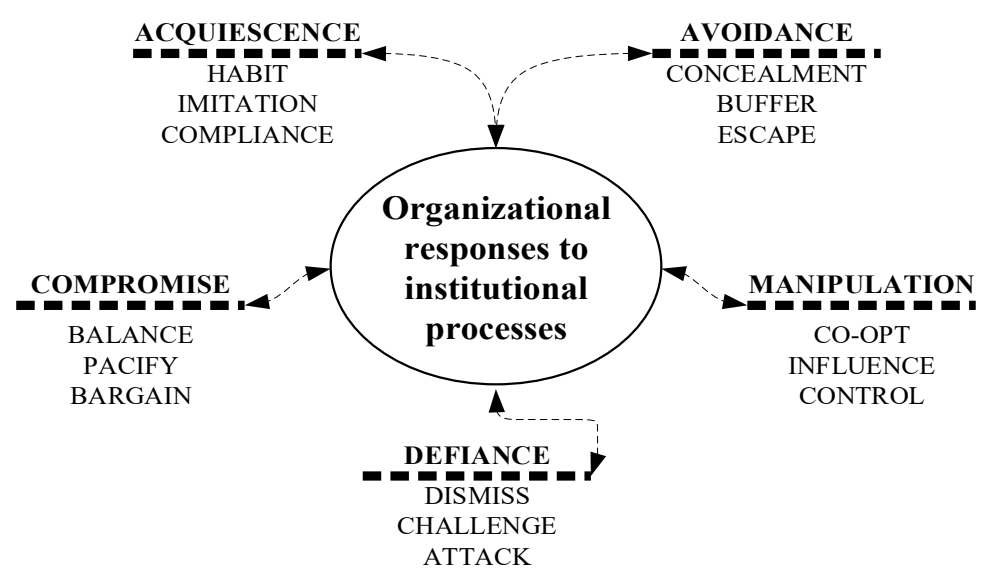

Figure 1. Organizational responses to institutional processes - Adapted by Oliver (1991)

In order to identify certain behaviors, in relation to the above mentioned normative dictation and taking into account the categories presented by Oliver (1991), it was necessary to proceed through a space-time analysis related to the Italian Regions financial statements (if present), published except for Regions with Special status.

Table 2. Sample regions analyzed - our elaboration

\begin{tabular}{lll}
\hline Northern & Central & Southern \\
\hline Liguria & Emilia-Romagna & Abruzzo \\
Lombardy & Lazio & Basilicata \\
Piedmont & Marchess & Calabria \\
Veneto & Tuscany & Campania \\
& Umbria & Molise \\
& & Apulia \\
\hline
\end{tabular}

The time period is considered starting from the year of the reform's implementation, for a total of 5 years (2012-2016).

\subsection{Clustering of Organizational Behaviors}

Considered the qualitative connotation of the analysis, the heterogeneity of the observations and the possible subjection to the perceptive variability, we tried to follow an approach able to create organizational behavioral categories related with the situations summarized on the basis of some indirect drivers, or the organizational response indicators: existence of the perimeter scheme, easiness of information research on the institutional web site (Transparent Administration Website section or Official Bulletin), Publication of the perimeter scheme as a single or separate document, Information fragmented in the document or in various documents, easiness of information research in the document or in different documents. The criteria of discernment and categorization taken into consideration, have been identified as follows:

- Easiness in the research of information;

- Actual publication;

- Publication in single or separate document;

- $\quad$ Fragmentary information; 
- Degree of interactivity for the quick search in the document (if present);

- Actual compliance with the regulation;

- Partial misalignment with the regulation;

- Total misalignment with the regulation.

Table 3. Indicators and strategies - our elaboration

\begin{tabular}{llll}
\hline Driver/ Indicator & Allignment & & \\
& Effective & Partial & Deficiency \\
\hline Effective publication & YES & NOT & NOT \\
Easy research of information on the institutional IT portal & YES & YES & NOT \\
Publication in single (U) or separate document (S) & S & U & U \\
Fragmented information & NOT & YES & YES \\
Easy research of information in the document/s & HIGH & MEDIUM/LOW & NULL/ NOT EXISTING \\
Strategy & Acquiescence & Compromise or Avoidance & Defiance \\
Tactic & Compliance & Pacify or Buffer & Dismiss \\
\hline
\end{tabular}

\subsection{Document Analysis}

The documents research was conducted by using search engines of the each Official Bulletins and the institutional web site section named Transparent Administration section of the sample related to the financial years period from 2012 to 2016, replicating the action of a "typical user".

In the following tables are indicated the document retrieved in the official registries of the Regional Councils and transparency websites.

Table 4. Founded documents per Region and year - Our elaboration $-\mathrm{NA}=$ Not Available, $X=$ Present

\begin{tabular}{|c|c|c|c|c|c|}
\hline Regione & 2016 & 2015 & 2014 & 2013 & 2012 \\
\hline Abruzzo & NA & NA & NA & NA & $\mathrm{X}$ \\
\hline Basilicata & NA & $\mathrm{X}$ & $\mathrm{X}$ & $\mathrm{X}$ & $\mathrm{x}$ \\
\hline Calabria & NA & NA & $\mathrm{X}$ & $\mathrm{X}$ & $\mathrm{X}$ \\
\hline Campania & NA & NA & NA & $\mathrm{X}$ & NA \\
\hline Emilia-Romagna & $\mathrm{X}$ & $\mathrm{X}$ & $\mathrm{X}$ & $\mathrm{X}$ & $\mathrm{X}$ \\
\hline Lazio & NA & $\mathrm{X}$ & $\mathrm{x}$ & $\mathrm{X}$ & NA \\
\hline Liguria & $\mathrm{X}$ & $\mathrm{x}$ & $\mathrm{x}$ & $\mathrm{x}$ & $\mathrm{X}$ \\
\hline Lombardy & $\mathrm{X}$ & $\mathrm{x}$ & $\mathrm{X}$ & $\mathrm{X}$ & $\mathrm{X}$ \\
\hline Marches & NA & $\mathrm{X}$ & $\mathrm{X}$ & $\mathrm{X}$ & $\mathrm{X}$ \\
\hline Molise & NA & $\mathrm{X}$ & $\mathrm{X}$ & $\mathrm{X}$ & NA \\
\hline Piedmont & $\mathrm{X}$ & $\mathrm{X}$ & $\mathrm{X}$ & $\mathrm{X}$ & $\mathrm{X}$ \\
\hline Apulia & $\mathrm{X}$ & $\mathrm{X}$ & $\mathrm{X}$ & $\mathrm{X}$ & NA \\
\hline Tuscany & $\mathrm{X}$ & $\mathrm{X}$ & $\mathrm{X}$ & $\mathrm{X}$ & $\mathrm{X}$ \\
\hline Veneto & $\mathrm{X}$ & $\mathrm{X}$ & $\mathrm{X}$ & $\mathrm{X}$ & $\mathrm{x}$ \\
\hline Umbria & $\mathrm{X}$ & $\mathrm{x}$ & $\mathrm{X}$ & $\mathrm{X}$ & $\mathrm{x}$ \\
\hline
\end{tabular}

Taking into account the provisions of the legislative decree 118/2011 at the article 20, the regions "in the ambit of the regional financial statement, guarantee an exact perimeter of the income and expenses related to the financing of their health service", the purpose it should be to guarantee the "immediate comparability between the income and expenses recorded for health care related with the regional financial statements and the resources mentioned in the official acts for determining the standard regional healthcare needs and identifying the related financing resources". That assumes two aspects, on the one hand, to show public information on the use of money taken from citizens coercively, on the other hand the role to make easier and support the auditors' work (be them internal, external and institutional). In practice, is highlighted in some specific cases and only in the minority of these, an acceptance (Acquiescence) and effective application of the norm in a detailed and strongly manner based on conformity (Compliance), understood as a conscious obedience to requests. There are various behaviors aimed at compromising (Compromise), specifically oriented to the application of a minimum standard 
(Pacifying), in other cases there is a tendency to avoidance (Avoidance) aimed to the reduction of the control measure (Buffering). In the majority of the cases there are clear resistance attempts (Defiance) that take shape of rejection (Dismissing) against the normative dictate.

\section{Analysis}

\subsection{Organizational Strategic Responses to External Institutional Pressure}

Although the observations in this way reported are indicative, respectively at the frequency per year of certain behaviors implemented in response to external institutional pressure and although limiting subjectivity, it may be present. It is shown that only in a minority of cases there is an acceptance (Acquiescence) which results in an effective compliance (Compliance). For the most recent years there has been a decline in the behaviors of evasive response (Avoidance), which resulted in a reduction of control measures, and in compromise response (Compromise), through the application of a minimum required. However, both the opposite positions of resistance (Defiance), which outcome is ultimately a rejection, and compliance (Acquiescence), have grown through the years. This could be symptomatic and would show, in the observations reported, that the organizational response tends to shift towards more extreme positions over the time. On the other hand, not appear clear imitative behaviors of isomorphism related with the possible best practices (Acquiescence Compliance) identified, which in fact it is confirmed only a single observation unit (from 2012 to 2015) and a second unit has been added only for 2016. On the contrary, a high number of observations is situated on resistance strategies (Defiance). The following figure explains graphically the trend of the responses over time.

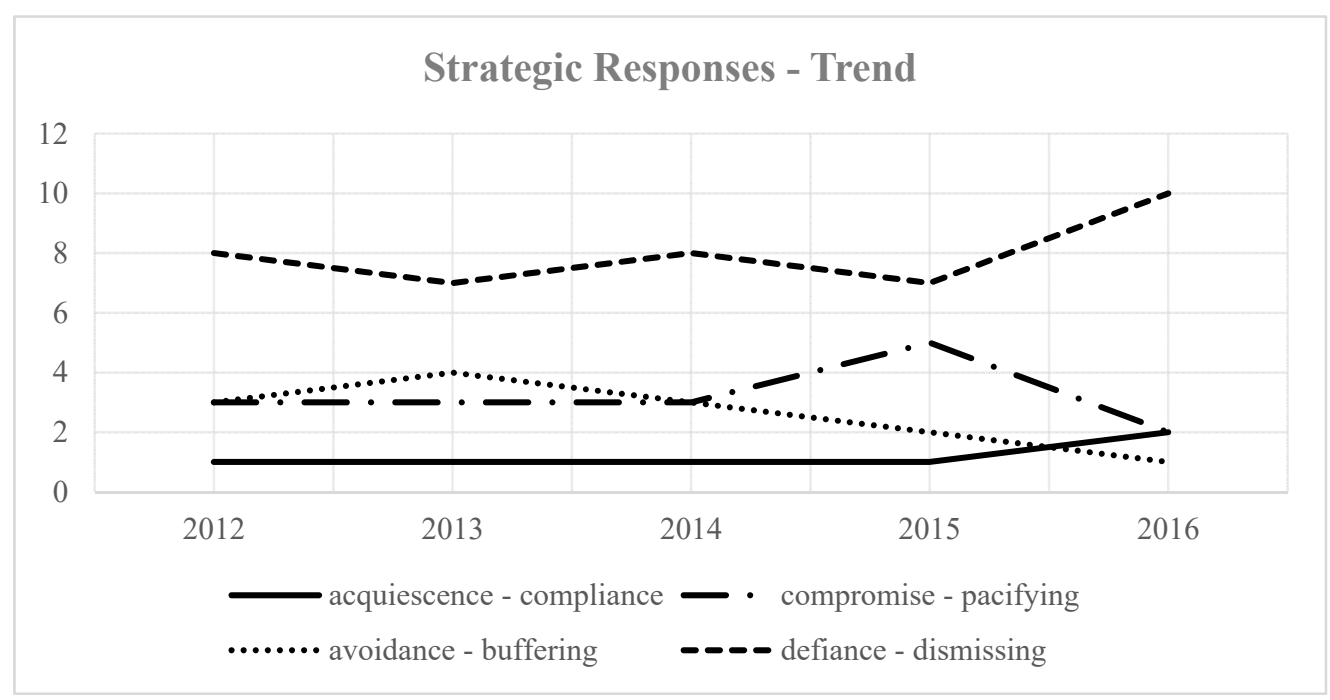

Figure 2. Strategic responses trend - Our elaboration

\subsection{Connection between Organizational Responses and Reporting Purposes}

Considering what has been said previously, in relation to the organizational strategic behavioral responses (in our case, Regions), and of what is evident in the international literature on "Accounting and Organization" (Miller and Power, 2013), the purposes that reporting must pursue can be traced by four specific cases reported in the following table.

Table 5. Accounting purposes - Adapted by Miller and Power, 2013

\begin{tabular}{ll}
\hline Accounting purposes & \\
\hline 1) Defining "Territory" & Territorializing \\
2) Informative intermediation & Mediating \\
3) Possibility of judgement & Adjudicating \\
4) Subjectivizing & Subjectivizing \\
\hline
\end{tabular}

As expressed, regarding to the perimeter of the income and expenditure of regional health services, it represents an important instrument to account and report aimed to achieve the four aforementioned purposes, being inherent to the underlined intellectual concept the willingness to attempt the construction of an informed context that ensures consciousness on the management results (Territorializing), communicating the factual status and the 
interpretative and evaluative position of the aspects related with management (Mediating), nevertheless, the possibility to be under the stakeholders' judgment (Adjudicating) and to be under the competent bodies' control (Subjectivizing).

For example, we tried to link the both aspects, organizational response to the external institutional pressure (Acquiescence-Compliance, Compromise-Pacifying, Avoidance-Buffering, Defiance-Dismissing) and the possible impact on the purposes of reporting (Territorializing, Mediating, Adjudicating, Subjectivizing), correlating each case with an achievement degree (strong - partial - weak - poor). The following table summarizes the number of observations and the related year. Taking into account what has been said, we want to show that, implementing organizational behavioral responses characterized by Acquiescence (Compliance), the four accounting purposes mentioned above are satisfied with an high achievement degree and identified with the term "strong".

This implies the real construction of an informed context (Territorializing), a strong external communication regarding the state of fact, nevertheless an own interpretative position on management (Mediating), favoring the possibility of subjection to the stakeholders' judgment (Adjudicating) and a rapid control by competent bodies (Subjectivizing). Compromise (Compromise) and evasive (Avoidance) behaviors, however, tend to provide information aimed to Territorializing and Mediating, in the first case with a "strong" meaning, in the second one "partial"; the greater discrepancy to compliance, is found on the aspects of Adjudicating and Subjectivizing in which we note "partial" meanings for the first case, "weak" for the second.

This is the base for various interpretations that are lost in the shades of the terms, shaping a clear and reiterated framework, in which the difficulty in obtaining information and their fragmentation, involve problems related to the actual purposes of reporting, that in fact often, while fulfilling their regulatory purpose, may not comply with the ideal one, hiding the intelligibility. Finally, the achievement degree increases but "in peius" (make worse), when the two purposes mentioned above (Adjudicating and Subjectivizing) takes the meaning "scarce / absent".

In conclusion, it would be better to be able to direct these behaviors towards an effective application (Compliance), sensitizing organizations to the punctual normative application and making the reporting format as uniform as possible, opting also for a separate publication of the document, that undoubtedly would facilitate subjection to stakeholder judgment and control. These measures would make more intuitive the research of information about the perimeter, favoring virtuous behaviors, guaranteeing the comprehensibility and the usefulness of reporting related with the purposes described above and more in general its intelligibility.

Table 6. Organizational responses and perimeter role related with the theoretical framework - Our elaboration

\begin{tabular}{lllll}
\hline Organizational responses & Territorializing & Mediating & Adjudicating & Subjectivizing \\
\hline Acquiescence (Compliance) & Strong & Strong & Strong & Strong \\
Compromise (Pacify) & Strong & Strong & Partial & Partial \\
Avoidance (Buffer) & Partial & Partial & Weak & Weak \\
Defiance (Dismiss) & Partial & Partial & Scarce/Absent & Scarce/Absent \\
\hline
\end{tabular}

Table 7. Organizational responses per year - Our elaboration

\begin{tabular}{lll}
\hline Year & Organizational responses & Observations \\
\hline \multirow{3}{*}{2012} & Acquiescence (Compliance) & 1 \\
& Compromise (Pacify) & 3 \\
& Avoidance (Buffer) & 3 \\
& Defiance (Dismiss) & 8 \\
& Acquiescence (Compliance) & 1 \\
& Compromise (Pacify) & 3 \\
& Avoidance (Buffer) & 4 \\
& Defiance (Dismiss) & 7 \\
& Acquiescence (Compliance) & 1 \\
& Compromise (Pacify) & 3 \\
& Avoidance (Buffer) & 3 \\
& Defiance (Dismiss) & 8 \\
& Acquiescence (Compliance) & 1 \\
& Compromise (Pacify) & 5 \\
& Avoidance (Buffer) & 2 \\
\hline
\end{tabular}




\begin{tabular}{lll}
\hline & Defiance (Dismiss) & 7 \\
& Acquiescence (Compliance) & 2 \\
& Compromise (Pacify) & 2 \\
& Avoidance (Buffer) & 1 \\
& Defiance (Dismiss) & 10 \\
\hline
\end{tabular}

\section{Comment and Conclusion}

Business economics should build up on the people's needs, with the organizations and businesses that fulfill their requirements; in the same way, the Health Care organizations ought to build up on the satisfaction of the health care needs (Büchi et al., 2013a, 2013b; Rainero \& Migliavacca, 2017). Taking into account what expressed, it would be appropriate to aggregate the "health care need" with the "safety" and "knowledge" ones, in a "liquid society" context, in which the state of fluidity creates a continuous and inexorable change of shape. This fluids' peculiarity, unlike solid bodies, makes able to never maintain a defined perimeter and they are always subjected to modification, by contrast there are the solids which are statics; in other words, fluids neither fix space nor bind time.

This is the metaphor that Zygmut Bauman used to identify the current phase of the modern era (Bauman, 2013a). Although the context of society in the ethereal sense is to be understood as a "liquid", in line of trend foreign from the space-time aspects, this may not have the same meanings in the corporate ambit. As a person, each company takes a dimension "in space" and "in time. Realizing the need to monitor performance in terms of financial resources' creation or consumption, production factors and wealth, nevertheless under "social" aspects (impact generation, positive or negative, on society, the environment, workers, the communities in which it operates, according to "non-financial" and sustainability criteria), companies materialize their space-dimension. It also assumes a time-dimension, being management characterized by the turning of events in a recurring and periodic way, and then the capability of the company to survive. In fact, the global context is pregnant of uncertainty, insecurity (Bauman, 2013b) and speed.

This one understood as the effect of the two primary conditions, due to the fact that individuals find their security in speed of actions. Quoting Ralph Waldo Emerson: "in skating over thin ice our safety is in our speed" (Emerson, 1870), we want to show how people yearn for safety by increasing their speed and the salvation frenzy. Slowing down, while the individual skate on thin ice, would imply the risk of reducing its tightness. Maslow shows in its theoretical hierarchical ladder that the security-need is placed immediately after physiological-needs (Maslow, 1998), therefore, it has a primary importance for people and their survival. Thus, at the apex of the pyramid, there is the self-realization need, which inevitably incorporates self-awareness and self-accountability in relation to the others; a relationship, today overshadowed by what Ulrich Beck calls “organized irresponsibility” (Beck, 2001).

In contrast, there is the base dearest to us, that is the possibility of recognizing in social accounting a practice and a social and institutional mentality. Studying accounting in the ambit of a strategic- organizational framework, means to relate it with solicitations, understanding that the used instruments are government tools, but unavoidably subjected to accountability mechanisms (Stacchezzini, 2012). This idea can be defined as: "the fact or condition of being accountable; responsibility" (Pearsall and Hanks, 1998). The term would derive from the Latin "accomptare", an equivalent of the verb "to account", from which ultimately derives "accounting". If from the responsibility derives etymologically the responsibility to account and report, then focused on the analysis, we can conclude, considering the goals that accounting and reporting processes pursue, as a central and very important role.

As expressed, responsible actions in terms of reporting should be put as a basis of an informed context, overcoming the need for knowledge and making the recipients aware. Therefore, reducing the spasmodic speed with which people and by reflex organizations are called to work for their survival and giving more space to an accurate, clear, streamlined, usable, intelligible and effective reporting, it would ensure a wider internal and external awareness, in general, on the management results and in detail, as expressed by the object of the study (Article 20 of Legislative Decree 118/2011) regarding "transparency of accounts and resources allocation for the financing of each regional health services", it would be possible to translate the possibility of submission to the stakeholders' judgment and the control by the competent bodies, in a better way of health care need satisfaction, moving a step towards a less liquid and uncertain society.

\section{References}


Abernethy, M. A., \& Stoelwinder, J. U. (1995). The role of professional control in the management of complex organizations. Account. Organ. Soc., 20, 1-17.

Büchi, G., Allais, R., Cane, M. R., Carignano, R., Comoglio, A., Indelicato, A., Puddu, L., Rainero, C., Ruffino, E. D., Trovato, G., Vajo, F., Vanner, A., \& Zollesi, G. (2013). Metodologie di benchmarking nel settore pubblico: applicazioni alla Sanità Piemontese 1-115.

Büchi, G., Puddu, L., Indelicato, A., Rainero, C., Ruffino, E. D., Puddu, E., Trovato, G., Vanner, A., Zollesi, G., \& Allais, R. (2013b). Aspetti del benchmarking nel settore sanitario pubblico: applicazioni al piemonte $1-122$.

Burt, R. S. (1983). Corporate profits and cooptation: Networks of market constraints and directorate ties in the American economy. Academic Press.

Clemens, B. W., \& Douglas, T. J. (2005). Understanding strategic responses to institutional pressures. J. Bus. Res., Special Section: Inter-organisational Research in the Nordic Countries 58, 1205-1213. https://doi.org/10.1016/j.jbusres.2004.04.002

Covaleski, M. A., \& Dirsmith, M. W. (1988). An institutional perspective on the rise, social transformation, and fall of a university budget category. Adm. Sci. Q., 562-587.

DiMaggio, P. (1988). Interest and agency in institutional theory. Institutional Patterns Organ. Camb., 1-21.

DiMaggio, P., Powell, W. W. (1983). The iron cage revisited: Collective rationality and institutional isomorphism in organizational fields. Am. Sociol. Rev. 48, 147-160.

Ferrero, G. (1968). Istituzioni di economia d'azienda. Giuffrè, Torino.

Galaskiewicz, J., \& Wasserman, S. (1989). Mimetic processes within an interorganizational field: An empirical test. Adm. Sci. Q., 454-479.

Greenwood, R., Raynard, M., Kodeih, F., Micelotta, E. R., \& Lounsbury, M. (2011). Institutional Complexity and Organizational Responses. Acad. Manag. Ann., 5, 317-371. https://doi.org/10.1080/19416520.2011.590299

Heimer, C. A. (1999). Competing institutions: Law, medicine, and family in neonatal intensive care. Law Soc. Rev., 17-66.

Hirschman, A. O. (1970). Exit, voice, and loyalty: Responses to decline in firms, organizations, and states. Harvard university press.

Hopwood, A. G., \& Miller, P. (1994). Accounting as social and institutional practice. Cambridge University Press.

Hoque, Z., Parker, L. D., Covaleski, M. A., \& Haynes, K. (2017). The Routledge Companion to Qualitative Accounting Research Methods.

Kitchener, M. (2002). Mobilizing the logic of managerialism in professional fields: The case of academic health centre mergers. Organ. Stud., 23, 391-420.

March, J. G. (1987). Ambiguity and accounting: The elusive link between information and decision making. Account. Organ. Soc., 12, 153-168.

Meyer, J. W. (1983). Centralization of funding and control in educational governance. Organ. Environ. Ritual Ration, 179-197.

Meyer, J. W., \& Rowan, B. (1977). Institutionalized organizations: Formal structure as myth and ceremony. Am. J. Sociol, 83, 340-363.

Meyer, J. W., \& Scott, W. R. (1992). Organizational environments: Ritual and rationality.

Meyer, J., Scott, W. R., \& Strang, D. (1987). Centralization, fragmentation, and school district complexity. Adm. Sci. Q., 186-201.

Migliavacca, A., Rainero, C., \& Puddu, L. (2016). Aziende, Amministrazione Razionale e Impatto Sociale.

Miller, P., Power, M. (2013). Accounting, Organizing, and Economizing: Connecting Accounting Research and Organization Theory. Acad. Manag. Ann. 7, 557-605. https://doi.org/10.1080/19416520.2013.783668

Modell, S. (2001). Performance measurement and institutional processes: a study of managerial responses to public sector reform. Manag. Account. Res., 12, 437-464. https://doi.org/10.1006/mare.2001.0164 
Nigam, A., \& Ocasio, W. (2010). Event attention, environmental sensemaking, and change in institutional logics: An inductive analysis of the effects of public attention to Clinton's health care reform initiative. Organ. Sci. $21,823-841$.

Oliver, C. (1991). Strategic responses to institutional processes. Acad. Manage. Rev. 16, 145-179.

Pache, A. C., \& Santos, F. (2010). When Worlds Collide: The Internal Dynamics of Organizational Responses to Conflicting Institutional Demands. Acad. Manage. Rev. 35, 455-476.

Pennings, J. M. (1980). Interlocking directorates. Jossey-Bass Inc Pub.

Perrow, C. (1985). Overboard with myth and symbols. University of Chicago Press.

Powell, W. W., \& Friedkin, R. (1986). Politics and programs: Organizational factors in public television decision making. Nonprofit Enterp. Arts, 245-269.

Powell, W.W. (1985). The institutionalization of rational organization.

Powell, W.W. (1988). Institutional effects on organizational structure and performance. Institutional Patterns Organ. Cult. Environ. 115-136.

Puddu, L., \& Di Russo, D. (2013). Manuale di ragioneria pubblica 1-330.

Puddu, L., Rainero, C., Scagliola, L., \& Lusa, C. (2016). La certificazione dei processi amministrativi nelle aziende sanitarie 1-264.

Rainero, C., \& Migliavacca, A. (2017). Managerial e cost accounting nelle aziende sanitarie, in: Management Dei Servizi Sanitari Territoriali. Efficienza e Valorizzazione Sociale. Publiedit, Cuneo.

Rainero, C., Puddu, L., Tradori, V., Secinaro, S., Indelicato, A., Migliavacca, A., \& Brescia, V. (2016). Risk management and healthcare: "separation" of revenues and expenditure 248-265.

Reay, T., \& Hinings, C. R. (2009). Managing the rivalry of competing institutional logics. Organ. Stud., 30, $629-652$

Salancik, G. R. (1979). Interorganizational dependence and responsiveness to affirmative action: The case of women and defense contractors. Acad. Manage. J., 22, 375-394.

Salancik, G. R., \& Pfeffer, J. (1978). A social information processing approach to job attitudes and task design. Adm. Sci. Q., 224-253.

Saunders, M., Lewis, P., \& Thornhill, A. (2009). Research Methods for Business Students. Pearson Education.

Scott, J. C. (1987). Resistance without protest and without organization: peasant opposition to the Islamic Zakat and the Christian Tithe. Comp. Stud. Soc. Hist., 29, 417-452.

Scott, R. (1983). The organization of societal sector. Organ. Environ. Ritual Ration, 129-153.

Scott, W. R. (2001). Instituitions and organizations. Thousande Oakes Sage.

Shipilov, A. V., Greve, H. R., Rowley, T. J. (2010). When do interlocks matter? Institutional logics and the diffusion of multiple corporate governance practices. Acad. Manage. J., 53, 846-864.

Smith, J. E., \& Smith, N. P., (1971). Readability: A measure of the performance of the communication function of financial reporting. Account. Rev. 46, 552-561.

Thompson, J. D. (1967). Organizations in action: Social science bases of administrative theory. Transaction publishers.

\section{Note}

Note 1. Art. 20, Legislative Decree n. 118/2011.

\section{Copyrights}

Copyright for this article is retained by the author(s), with first publication rights granted to the journal.

This is an open-access article distributed under the terms and conditions of the Creative Commons Attribution license (http://creativecommons.org/licenses/by/4.0/). 